\title{
Perancangan Website Sistem Seleksi Siswa Baru menggunakan Framework CodeIgniter Pada Madrasah Aliyah Alkhairaat Kalumpang Kota Ternate
}

\author{
Widiawati $^{1}$, Hairil Kurniadi Siradjuddin ${ }^{2}$ \\ ${ }^{1}$ Prodi Manajemen Informatika \\ Politeknik Sains dan Teknologi Wiratama Maluku Utara \\ ${ }^{2}$ Fakultas Teknik, Prodi Teknik Informatika \\ Universitas Khairun Ternate \\ widia.wati.250399@gmail.com
}

\begin{abstract}
Abstrak
Madrasah Aliyah Alkhairaat merupakan salah satu Sekolah Islami pada Kota Ternate. Sebagai sekolah yang memiliki peran besar bagi masyarakat luas tentunya sangat membutuhkan Teknologi Informasi seperti website untuk mengelola data maupun proses seleksi siswa baru. Tujuan penelitian ini adalah membuat Perancangan Website Sistem Seleksi Siswa Baru pada Madrasah Aliyah Alkhairaat Kalumpang Kota Ternate. Pengumpulan data pada penelitian ini menggunakan teknik wawancara dan observasi. Tahapan kemudian penelitian dimulai dari analisis sistem, perancangan sistem, dan pengembangan sistem. Metode analisis sistem adalah metode terstruktur dengan menggunakan model bottom-up, untuk perancangannya menggunakan metode berorentasi objek sedangkan untuk pengembangannya menggunakan metode Prototyping. Sistem ini dirancang dengan Alat Bantu UML (Unified Modeling Language), bahasa pemrograman yang di gunakan adalah $H T M L, C S S$, dan PHP, Database dibuat menggunakan MySQL. Penelitian menghasilkan website seleksi siswa baru pada Madrasah Aliyah Alkhairaat Kota Ternate yang memudahkan pihak sekolah pada proses pengelolaan data seleksi serta menginformasikan pengumuman kelulusan, untuk siswa baru dapat memudahkan proses seleksi dan pengumuman kelulusan siswa baru dimana saja, tanpa harus datang ke sekolah terkait.
\end{abstract}

\section{Kata Kunci: Perancangan Sistem Website, Seleksi Siswa baru}

\section{Abstract}

Madrasah Aliyah Alkhairaat is one of the Islamic Schools in Ternate City. As a school that has a significant role for the wider community, of course, need Information Technology such as websites to manage data and the selection process of new students. The purpose of this study was to create a New Student Selection System Website Design at Madrasah Aliyah Alkhairaat Kalumpang Ternate City. Data collection in this study uses interview and observation techniques. The next stage of research starts with system analysis, system design, and system development. The system analysis method is a structured method using a bottomup model, for the design using object-oriented methods while for its development using the Prototyping method. This system is designed with UML (Unified Modeling Language) Tools. The programming languages used are HTML, CSS, and PHP. The database is created using MySQL. The research produced a new student selection website at Madrasah Aliyah Alkhairaat Ternate City which made it easy for schools to manage the selection data and 
inform graduation announcements, for new students to facilitate the selection process and the announcement of new student graduations everywhere, without having to come to the relevant school.

\section{Keywords: Website System Design, New Student Selection}

\section{PENDAHULUAN}

Perkembangan teknologi informasi dalam era globalisasi saat ini sangatlah tumbuh dengan pesat. Perkembangan teknologi informasi saat ini memberi berbagai keuntungan dan kemudahan bagi manusia. Berbagai aspek kehidupan dan kegiatan memerlukan adanya teknologi informasi untuk menunjang kebutuhan mereka masing-masing. Oleh karena itu teknologi informasi merupakan elemen yang sangat penting yang tidak bisa dipisahkan dengan peradaban dunia saat ini.

Salah satu bukti berkembangnya teknologi informasi yang memiliki peran besar pada masyarakat adalah website. website sebuah situs pada umumnya terangkum dalam sebuah domain atau subdomain yang ditempatkan pada sebuah server web (hosting). Dengan website tentu dapat membantu masyarakat dalam hal mencari informasi serta mudah menyelesaikan pekerjaan baik dibidang bisnis, pendidikan, dan lainnya, karena website dapat diakses dimana saja dan kapan saja.

Berbagai penelitian telah dilakukan di sekolah, dan hampir semua sekolah mempunyai langkah yang sama dalam melakukan pendaftaran, seleksi, dan pengumuman kelulusan siswa baru. di jaman sekarang ini semua hal sudah dilakukan pada sistem termasuk proses pendaftaran, seleksi, dan pengumuman Kelulusan siswa baru. Namun hal ini belum di terapkan pada Madrasah Aliyah Alkhairaat Kalumpang Kota Ternate. Madrasah Aliyah Alkhairaat merupakan sekolah Islami yang memiliki peminat cukup banyak, santri yang tercatat saat ini berjumlah 250 santri.

Banyaknya santri yang mendaftar tentu membutuhkan waktu yang lama. Karena Proses pendaftaran, seleksi, dan pengumuman di Alkhairaat masih dilakukan secara Konvensional, yaitu siswa harus datang ke sekolah untuk melakukan pendaftaran, seleksi dan melihat pengumuman, sehingga membutuhkan waktu dan biaya yang cukup besar bagi siswa yang berada di luar daerah, dikarenakan siswa harus datang berulang-ulang hanya untuk melihat informasi pendaftaran, seleksi dan pengumuman. Tak hanya itu dalam hal mengelola data pendaftaran, seleksi, sampai pengumuman masih diinformasikan pada papan pengumuman kelulusan, Sehingga dianggap kurang efektif. Oleh karena itu dibutuhkan satu sistem informasi berbasis website.

Berdasarkan hasil uraian diatas maka diusulkan judul penelitian : "Perancangan Website Sistem Seleksi Siswa Baru menggunakan Framework CodeIgniter pada Madrasah Aliyah Alkhairaat Kalumpang Kota Ternate”.

\section{Rumusan Masalah}

Berdasarkan uraian latar belakang masalah diatas, maka rumusan masalah dari penelitian ini yaitu " Bagaimana Merancang Sistem Seleksi Siswa Baru pada Madrasah Aliyah Alkhairaat Kalumpang Kota Ternate?"

\section{Tujuan Penelitian}


Tujuan penelitian ini adalah Merancang Website Sistem Seleksi Siswa baru pada Madrasah Aliyah Alkhairaat Kalumpang Kota Ternate.

\section{Manfaat Penelitian}

Adapun Manfaat dari penelitian ini adalah sebagai berikut:

1. Mempermudah pihak sekolah dalam mengelola data pendaftaran, seleksi, dan menginformasikan pengumuman kelulusan.

2. Mempermudah Siswa Baru pada proses pendaftaran, seleksi, dan pengumuman dimana saja tanpa harus datang ke sekolah yang bersangkutan.

\section{Tinjauan Pustaka}

Penelitian yang dilakukan oleh Sugeng Priyanto (2018) yang berjudul Sistem Informasi Pendaftaran Mahasiswa Baru Berbasis Website pada Poltek Wiratama Maluku Utara. Tujuan penelitian ini diharapkan dapat mempercepat informasi pendaftaran dan pengumuman hasil calon mahasiswa baru melalui website, meningkatkan kinerja dan pelayanan pada Politeknik Sains \& Teknologi Wiratama Maluku Utara lebih efektif dan efisien. Serta dapat memudahkan admin mengelola data calon mahasiswa baru, mempercepat informasi pendaftaran dan pengumuman hasil calon mahasiswa baru melalui website, dan membantu panitia dalam penyeleksian calon mahasiswa baru untuk hal-hal yang berkaitan dengan pengaksesan data serta pemroses data, juga untuk meningkatkan kinerja dan pelayanan pada Politeknik Sains \& Teknologi Wiratama Maluku Utara lebih efektif dan efisien. Penelitian sistem informasi Pendaftaran Mahasiswa
Baru berbasis Website ini belum menyediakan tes secara online.

Penelitian yang di lakukan oleh Ika Yuniva (2018) yang berjudul Pendekatan Model Waterfall Dalam Perancangan Web Sistem Informasi Penerimaan Siswa Baru Menggunakan Framework Bootstrap. Tujuan penelitian ini agar pihak madrasah dapat memproses penerimaan siswa baru, pembayaran administrasi, serta laporan kelulusan siswa secara online. Hasil akhir dari perancangan website penerimaan siswa baru menggunakan bootstrap adalah laporan pendaftaran siswa, laporan kelulusan siswa, serta laporan pembayaran administrasi siswa baru pada sistem. Diharapkan dapat mempermudah kinerja user dalam hal melakukan pengelolaan data penerimaan siswa, laporan pendaftaran, kelulusan, dan laporan pembayaran secara online.

\section{LANDASAN TEORI Pengertian Sistem}

Secara garis besar sistem merupakan suatu kumpulan komponen dan elemen yang saling terintegrasi, komponen yang terorganisir dan bekerja sama dalam mewujudkan suatu tujuan tertentu, Menurut Sutanto dalam Djahir dan Pratita (2015:6) mengemukakan bahwa sistem adalah kumpulan/ grup dari subsistem / bagian /komponen apapun, baik fisik ataupun nonfisik yang saling berhubungan satu sama lain dan bekerja sama secara harmonis untuk mencapai satu tujuan tertentu.

\section{Karakteristik Sistem}

Suatu sistem mempunyai ciri-ciri karakteristik yang terdapat pada sekumpulan elemen yang harus dipahami dalam megidentifikasi pembuatan sistem. (Hutahaean, 2015:3) 


\section{Klasifikasi Sistem}

Sistem merupakan suatu bentuk integrasi antara satu komponen dan komponen lain karena sistem memiliki sasaran yang berbeda untuk setiap kasus yang terjadi di dalam sistem tersebut. Oleh karena itu sistem dapat diklasifikasikan dari beberapa sudut pandang. (Hutahaean, 2015:6)

\section{Pengertian Informasi}

Menurut Azhar Susanto (2013:38), Informasi merupakan hasil dari pengolahan data, akan tetapi tidak semua hasil dari pengolahan tersebut bisa menjadi informasi, hasil pengolahan data yang tidak memberikan makna atau arti serta tidak bermanfaat bagi seseorang bukanlah merupakan informasi bagi orang tersebut.

\section{Pengertian Sistem Informasi}

Menurut Sutarman (2012), Sistem Informasi adalah sistem dapat didefinisikan dengan mengumpulkan, memproses, menyimpan, menganalisis, menyebarkan, informasi untuk tujuan tertentu. Seperti sistem lainnya, sebuah sistem informasi terdiri atas input (data, instruksi) dan output (laporan, kalkulasi).

\section{Pengertian Seleksi}

Menurut Priansa (2016:106), Seleksi adalah serangkaian langkah kegiatan yang digunakan untuk memutuskan apakah pelamar diterima atau ditolak.

Menurut Kasmir (2016:101), Seleksi adalah proses untuk memilih calon karyawan yang sesuai dengan persyaratan atau standar yang telah ditetapkan.

Menurut Bangun (2012:159), Seleksi adalah proses memilih calon karyawan yang memiliki kualifikasi sesuai dengan persyaratan pekerjaan.
Menurut Yani dalam Sinambela (2012:140), Seleksi adalah suatu proses pemilihan calon tenaga kerja yang paling memenuhi syarat untuk mengisi suatu lowongan pekerjaan.

Dari beberapa teori diatas penulis menyimpulkan pengertian seleksi adalah proses pemilihan calon pekerja yang paling memenuhi persyaratan yang ditetapkan oleh manajemen untuk mengisi kekosongan lowongan pekerjaan.

\section{Pengertian Website}

Menurut Abdullah (2015:1), Web dapat diartikan sekumpulan halaman yang terdiri dari beberapa laman yang berisi informasi dalam bentuk data digital baik berupa text, gambar, video, audio, dan animasi lainnya yang disediakan melalui jalur koneksi internet.

\section{Pengertian Web Server}

Menurut Supono dan Putratama (2016:6) Web Server adalah perangkat lunak server yang berfungsi untuk menerima permintaan dalam bentuk situs web melalui HTTP atau HTTPS dari klien itu, yang dikenal sebagai browser web dan mengirimkan kembali (reaksi) hasil dalam bentuk situs yang biasanya merupakan dokumen HTML.

\section{Pengertian $M y S Q L$}

Menurut Hidayatullah dan Jauhari (2015:180) MySQL adalah salah satu aplikasi DBMS yang sudah banyak oleh para pemogram aplikasi web. Contoh DBMS lainnya adalah : PostgreSQL (freeware), SQLServer, MSAccess dari Microsoft, DB2dari IBM, Oracle dan Oracle Corp, Dbase, FoxPro, dsb.

\section{Pengertian $X A M P P$}


Menurut Kartini (2013:27-26) Xampp merupakan tool yang menyediakan paket perangkat lunak ke dalam satu buah paket.

\section{Pengertian CodeIgniter}

Menurut Supono dan Putratama (2016:109) Codeigniter adalah aplikasi open source yang berupa framework dengan model MVC (Model, View, Controller) untuk membangun website dinamis dengan menggunakan PHP .

\section{Pengertian $\boldsymbol{U M L}$}

Menurut Rosa dan Shalahuddin (2014:133) berpendapat bahwa, UML (Unified Modeling Language) adalah Salah standar bahasa yang banyak digunakan di dunia industri untuk mendefinisikan requerement, membuat analisa dan desain, serta menggambarkan arsitektur dalam pemrograman berorintasi objek.

\section{METODE PENELITIAN}

\section{Lokasi dan Waktu Penelitian}

Lokasi penelitian ini adalah pada Madrasah Aliyah Alkhairaat. Jl. Kakatua, Kalumpang, Kota Ternate Tengah, Maluku Utara.

\section{Metode Pengumpulan Data}

Metode pengumpulan data adalah langkah-langkah yang digunakan oleh peneliti untuk mendapatkan data dengan cara wawancara dan observasi. Wawancara yang dilakukan peneliti dengan cara tatap muka dan Tanya jawab langsung dengan Kesiswaan, Pimpinan, dan Siswa. sedangkan observasi dilakukan peneliti dengan mengamati sistem seleksi dan penerimaan siswa baru pada Madrasah Aliyah Alkhairaat Kalumpang Kota Ternate.

\section{Studi Kepustakaan}

Dengan mencari dan mengumpulkan data yang diperlukan dari berbagai Jurnaljurnal, Karya Tulis Ilmiah, Buku-buku, yang dapat menunjang dan menjadi referensi penyusunan laporan tugas akhir ini.

\section{Alur Penelitian}

Alur penelitian merupakan langkahlangkah perencanaan yang akan dilakukan dalam penelitian pengembangan sistem, berikut merupakan gambar alur penelitian yang akan digunakan :

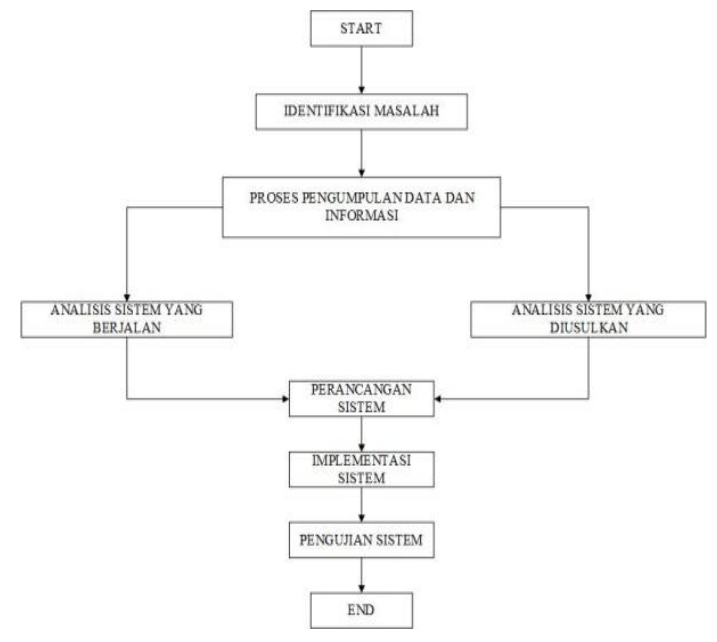

Gambar 1. Alur Penelitian

\section{Metode Pengembangan Sistem}

Metode pengembangan pembuatan sistem Seleksi dan Penerimaan Siswa Baru ini menggunakan metode Prototyping. Metode Prototyping merupakan metode pengembangan yang sangat cepat dan pengujian model kerja aplikasi baru yang dilakukan secara berulang-ulang, jadi jika terjadi kesalahan pada sistem maka dapat diulang kembali pada tahap awal.

Berikut merupakan tahapan penelitian dalam metode pengembangan sistem :

1. Pengumpulan kebutuhan

Pada tahap ini peneliti menganalisa dan mengidentifikasi kebutuhan sistem, dimana pengumpulan data dan 
penelitian dilakukan dengan cara wawancara dan observasi. Peneliti melakukan wawancara secara langsung atau tatap muka yaitu dalam bentuk tanya jawab kepada bagian kesiswaan, pimpinan, dan siswa itu sendiri. Sedangkan observasi dilakukan oleh peneliti dengan terlibat langsung pada proses seleksi dan penerimaan siswa baru.

2. Membangun Prototyping

Pada tahap ini peneliti merancang sistem dengan menggunakan pendekatan terstruktur dan pendekatan berorientasi objek, dimana peneliti mendesain sistem secara umum dengan menggunakan flowchart dan pendekatan bottom up pada sistem yang berjalan dan diusulkan, sedangkan untuk mendesain sistem secara rinci peneliti menggunakan UML Melalui alat bantu Microsoft Visio 2016.

3. Menggunakan Sistem

Pada tahapan ini peneliti akan mengevaluasi sistem dan melakukan perbincangan dengan user mengenai sistem yang akan dibuat, yaitu dengan cara screen setiap tahapan dan gambar sistem.

4. Mengkodekan Sistem

pada tahapan ini peneliti akan merancang pengkodean sistem yang telah disepakati oleh User dengan menggunakan bahasa pemrograman HTML, CSS, PHP dan lainnya.

5. Menguji system

Setelah sistem melalui beberapa tahapan seperti perancangan, pengkodean, maka sistem siap digunakan. namun sebelum itu sistem akan diuji terlebih dahulu dengan menggunakan metode Black box agar kesalahan pada sistem dapat diketahui.
6. Evaluasi system

Setelah sistem diuji dan siap untuk digunakan oleh user, maka tahap selanjutnya yaitu peneliti mengevaluasi kembali dengan cara memberikan quesioner pada User mengenai kinerja dari sistem.

7. Evaluasi Prototyping

Sistem yang telah dibuat melalui beberapa tahapan seperti pengujian sistem dan perbincangan kesepakatan antara peneliti dan user, maka sistem pun layak dan siap untuk digunakan.

\section{ANALISIS DAN PERANCANGAN}

Sistem yang berjalan pada Madrasah Aliyah Alkhairaat Kalumpang Kota Ternate dapat dideskripsikan sebagai berikut: diawali dengan siswa melihat jadwal beserta persyaratan pendaftaran, kemudian siswa mengambil formulir untuk diisi beserta persyaratannya, setelah melakukan pengisisan formulir kemudian dikumpulkan pada panitia, panitia melakukan validasi yaitu memeriksa formulir serta persyaratan yang dikumpulkan oleh siswa. Jika pengisian formulir masih terdapat kesalahan atau persyaratan yang dikumpulkan kurang lengkap siswa diminta untuk melengkapi dan mengisi formulir kembali, namun jika berhasil maka siswa akan di tes, adapun tes yang akan diujikan adalah tes ngaji, tes tulis, dan wawancara. Panitia mengumumkan hasil verifikasi kelulusan siswa, jika siswa tidak lulus maka siswa dapat mengikuti gelombang berikutnya, namun jika siswa lulus diwajibkan melakukan pembayaran yaitu biaya pendaftaran dan biaya administrasi. panitia membuat tanda bukti pembayaran yang nantinya akan diberikan pada pimpinan untuk ditandatangani. 
Dari permasalahan yang sudah teridentifikasi pada sistem yang sedang berjalan maka peneliti mengusulkan sebuah sistem yang diharapkan dapat memudahkan pengelolaan data pendaftaran, seleksi, dan pengumumuman kelulusan bagi admin, serta memudahkan siswa baru dalam hal melakukan pendaftaran, tes, dan pengumuman kelulusan siswa. Berikut merupakan alur sistem yang diusulkan:

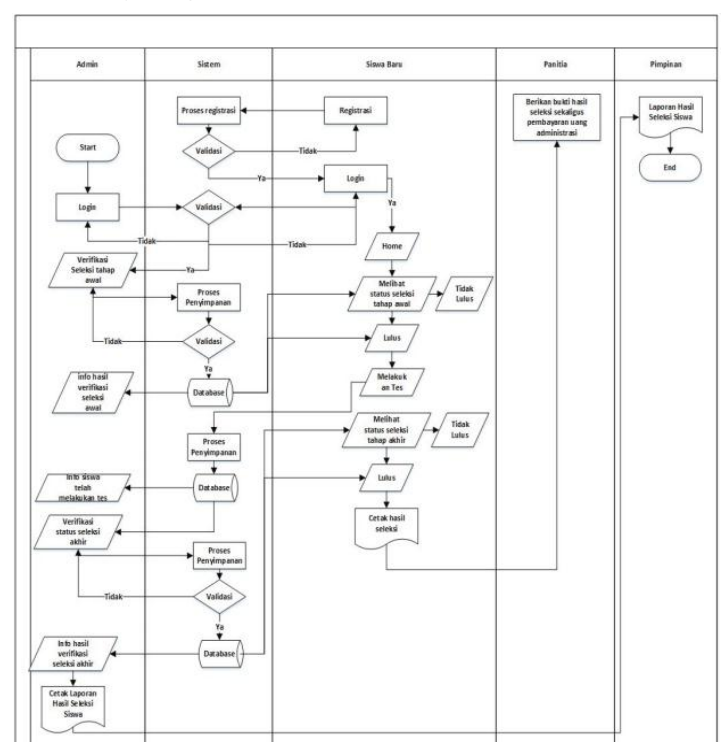

Gambar 2. Analisis Sistem yang diusulkan

\section{Kebutuhan Perangkat}

Perangkat keras (Hardware) dengan spesifikasi yaitu:

1. Laptop Acer

2. Processor Intel (R) Celeron (R), CPU N3350@1.10GHz, RAM 2,00 GB.

3. Printer Canon IP 430

4. Hardisk $320 \mathrm{~GB}$

Sedangkan perangkat lunak (Software) yang digunakan untuk penelitian ini ada sebagai berikut:

1. Sistem Operasi Windows 10

2. Microsoft Visio 2016 untuk membuat diagram flowchart

3. HTML, CSS dan PHP sebagai script Programming
4. MySQL untuk database

5. Browser seperti Mozilla Firefox

6. Xampp 3.2.1 sebagai server

7. Sublime Text sebagai penyunting kode

8. CSS untuk mendesain tampilan web

9. Framework CodeIgniter untuk mebuat website

\section{Rancangan Tabel}

Tabel 1. Tabel Admin

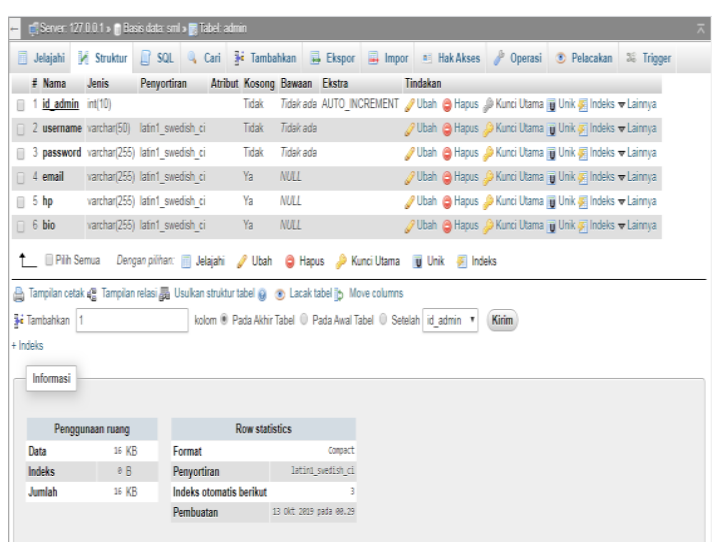

Tabel 2. Tabel Calon Siswa

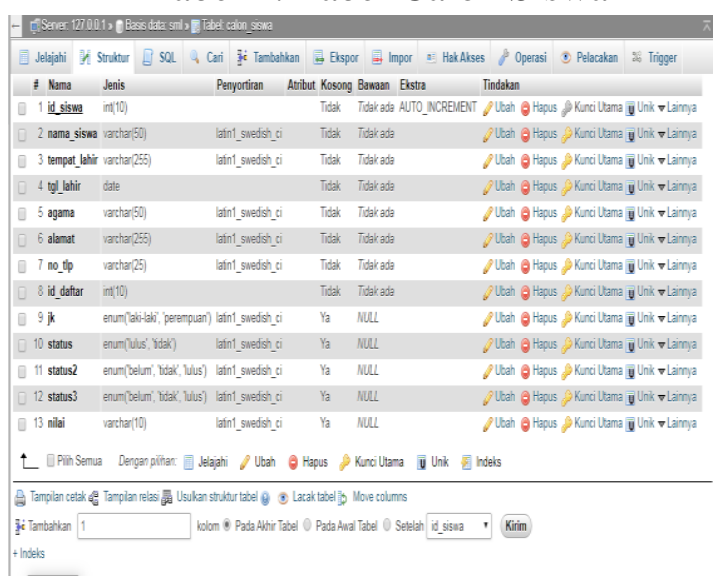

Tabel 3. Tabel Jalur Pendaftaran

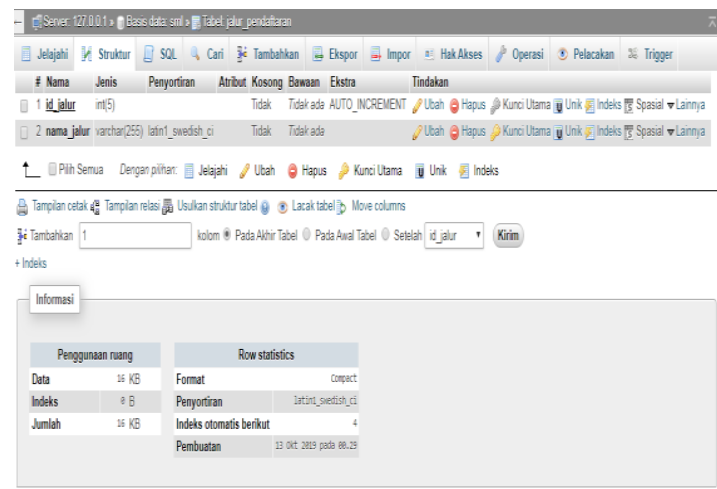




\section{Use Case Diagram}

Use case diagram merupakan bagian tertinggi dari fungsionalitas yang dimiliki sistem yang akan menggambarkan bagaimana seseorang atau aktor akan menggunakan atau memanfaatkan sistem. berikut merupakan use case diagram sistem seleksi siswa baru:

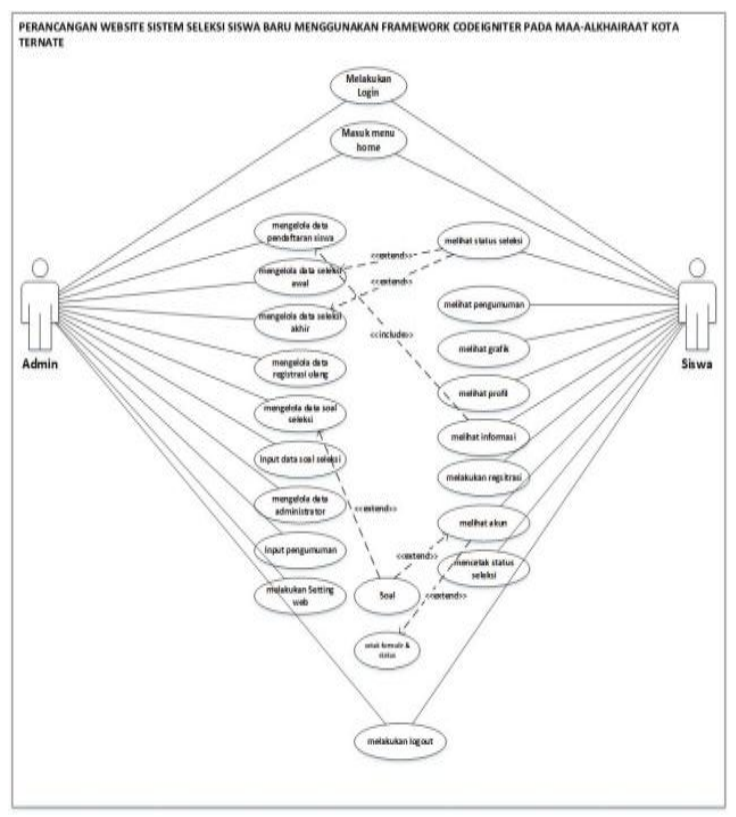

Gambar 3. Use Case Diagram

\section{Activity Diagram}

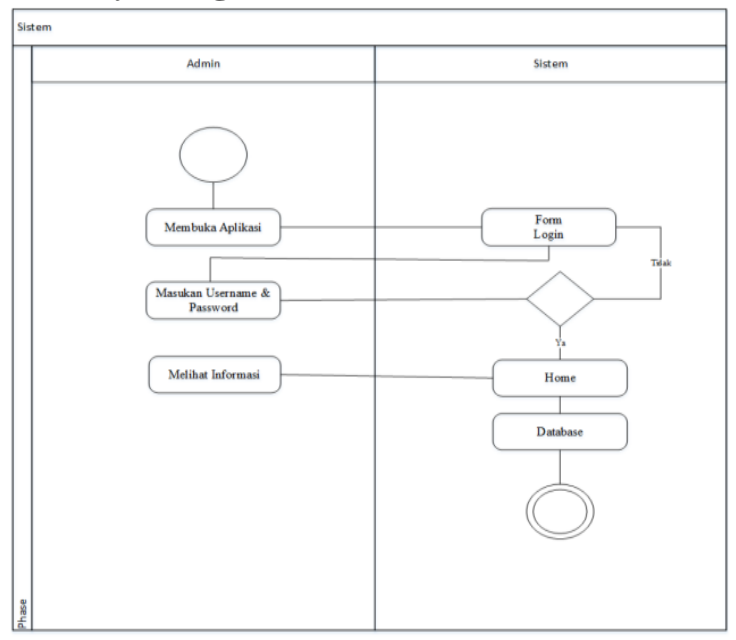

Ganbar 4. Activity Login Admin

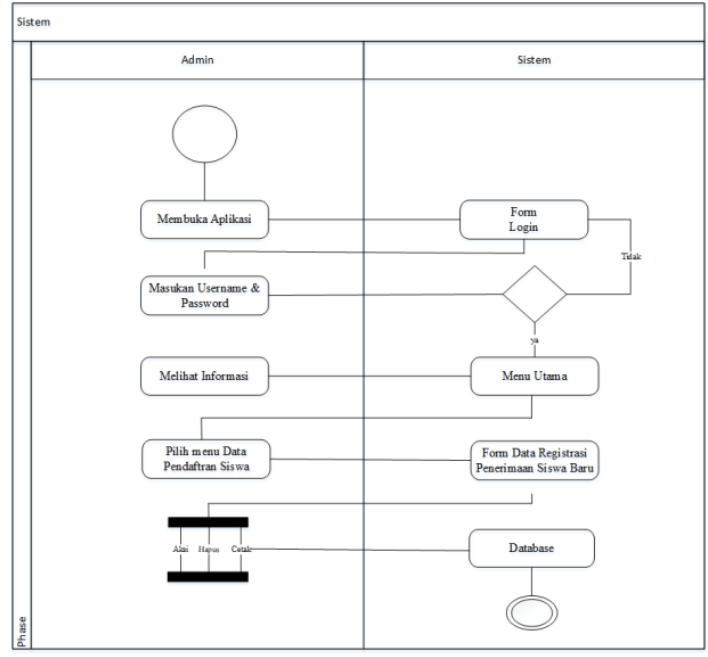

Gambar 5. Activity kelola registrasi siswa

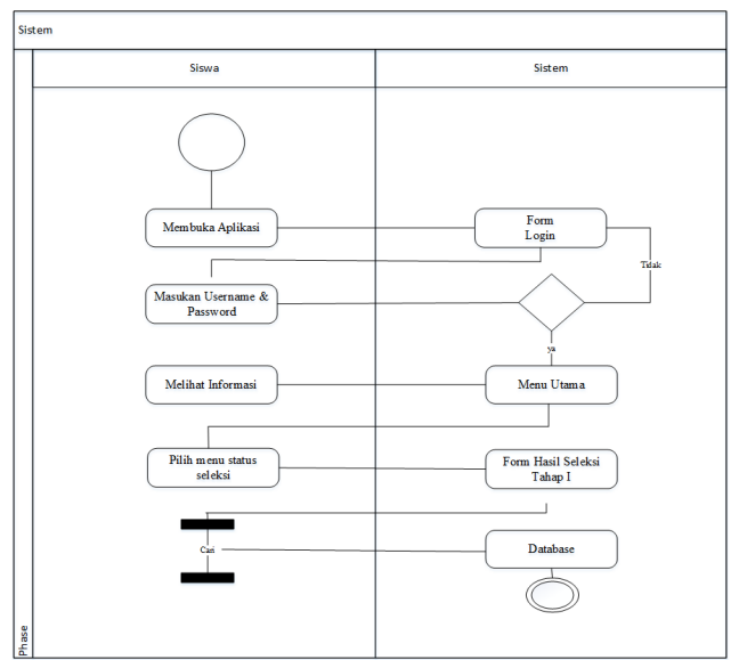

Gambar 6. Activity status seleksi siswa

\section{Class Diagram}

Class diagram menggambarkan struktur statis class di dalam sistem. Class merepresentasikan sesuatu yang ditangani oleh sistem. Dengan melihat karakteristik sistem seleksi siswa baru yang dimulai dari bagian pendaftaran siswa baru, seleksi siswa sampai dengan proses-proses yang terjadi, maka dapat dibuat class diagram. Berikut merupakan class diagram perancangan website sistem seleksi siswa baru pada Madrasah Aliyah Alkhairaat Kalumpang Kota Ternate: 


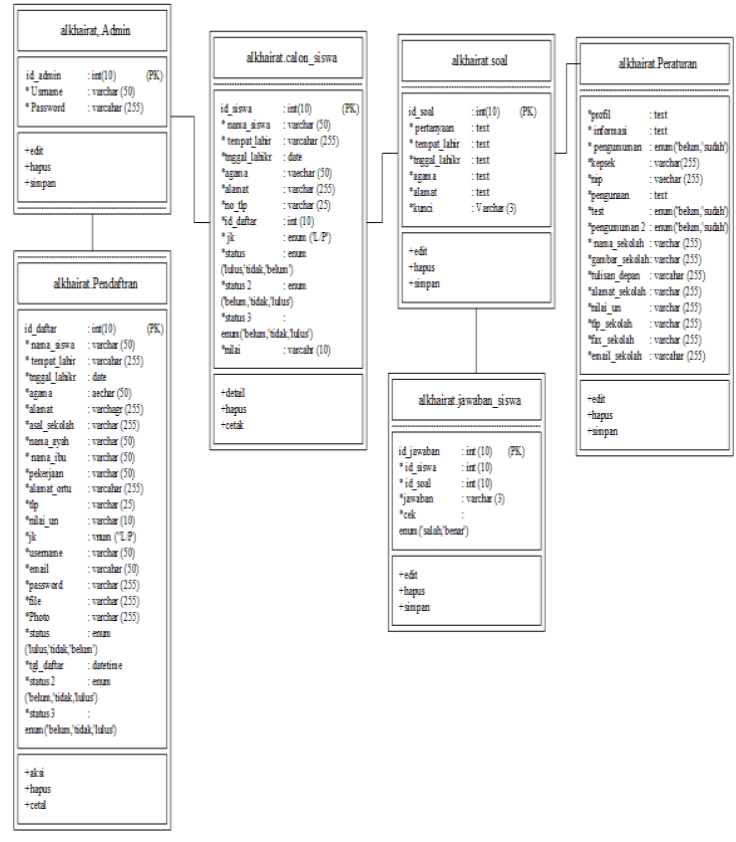

Gambar 7. Class Diagram

IMPLEMENTASI DAN PEMBAHASAN Form Login Admin

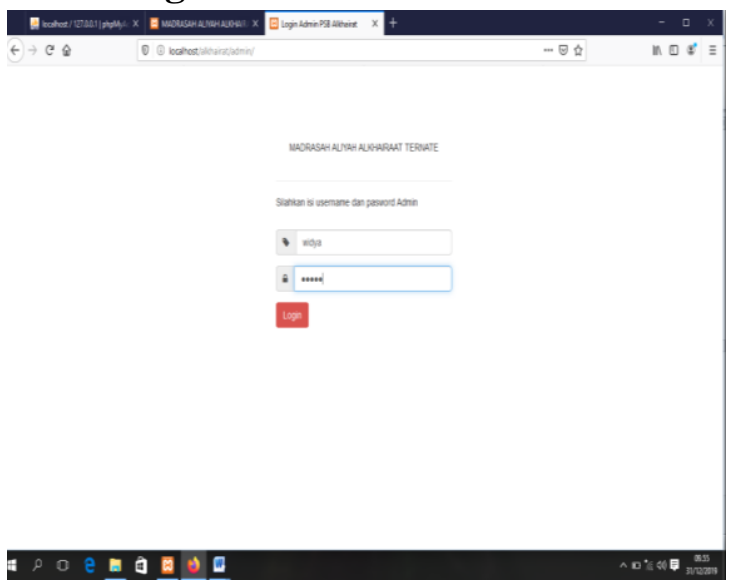

Gambar 8. Form login admin

Tampilan Home Admin

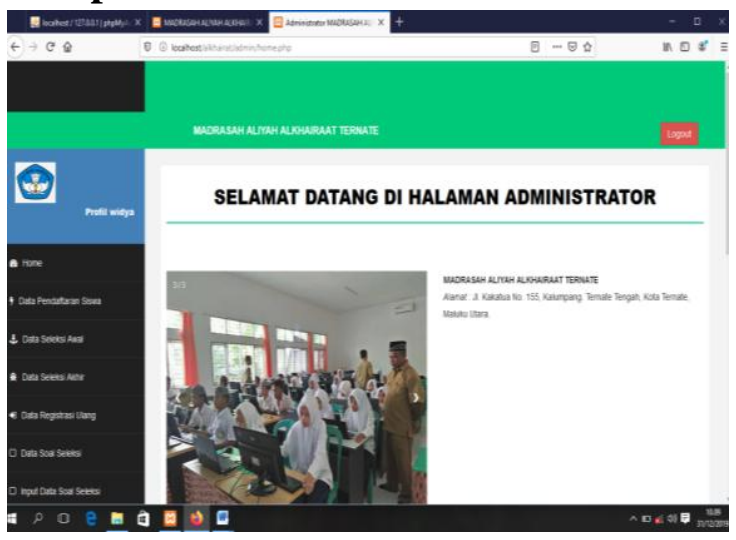

Gambar 9. Tampilan Home Admin
Tampilan Kelola Data Soal Seleksi

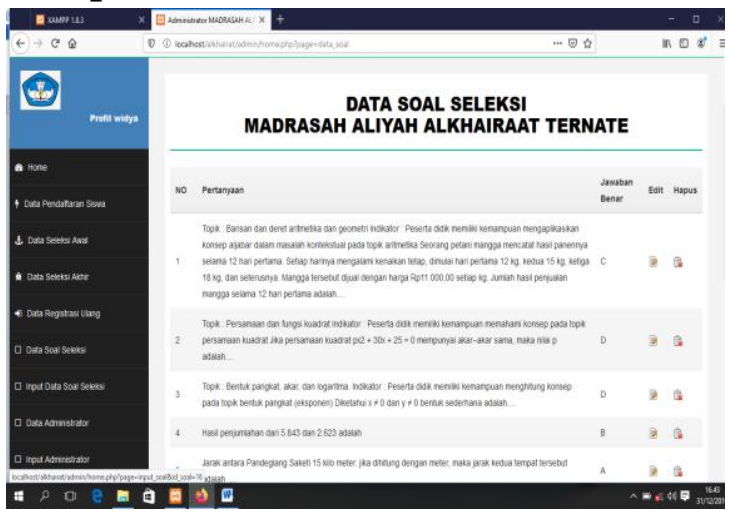

Gambar 10. Tampilan data soal seleksi

\section{Form Cetak Hasil Seleksi siswa}

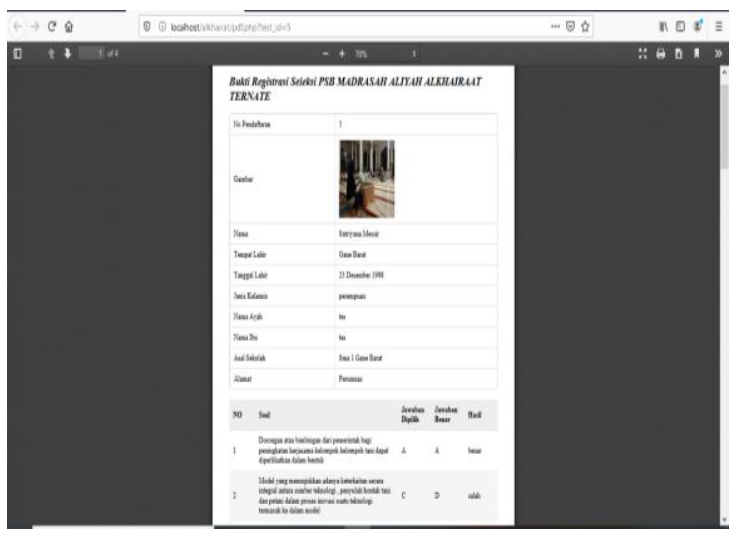

Gambar 11. Form cetak hasil seleksi siswa

\section{Form Awal Registrasi Siswa}

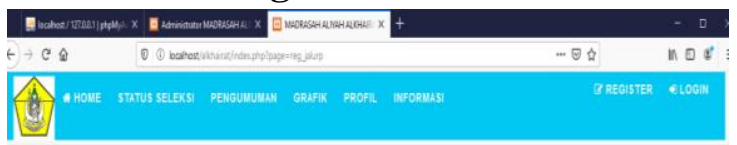

Pendaftaran Penerimaan Siswa Baru 2020

$$
\text { Pili Jalu Pendatararab }
$$
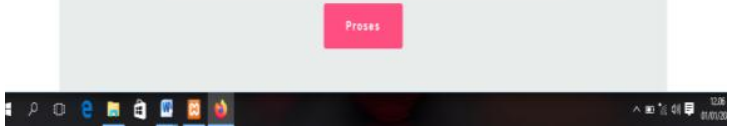

Gambar 12. Form awal registrasi siswa

\section{Halaman Registrasi Siswa}




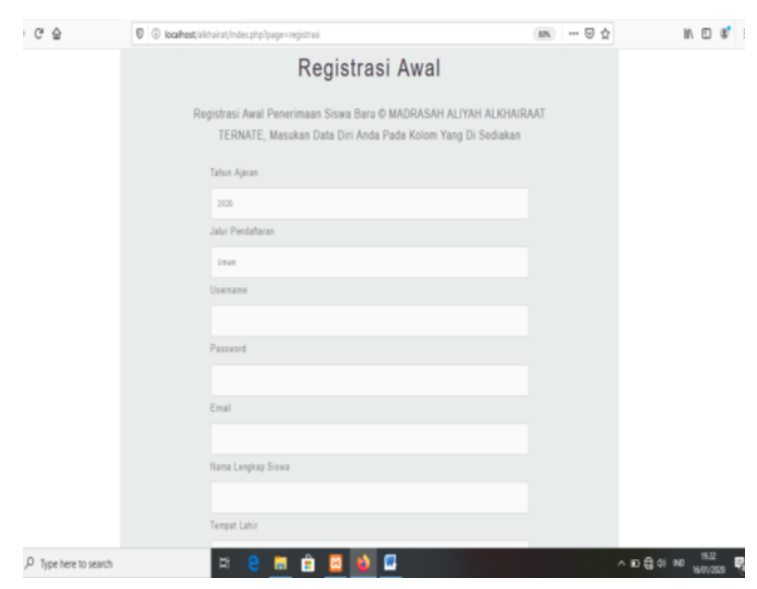

Gambar 13. Halaman Registrasi Siswa

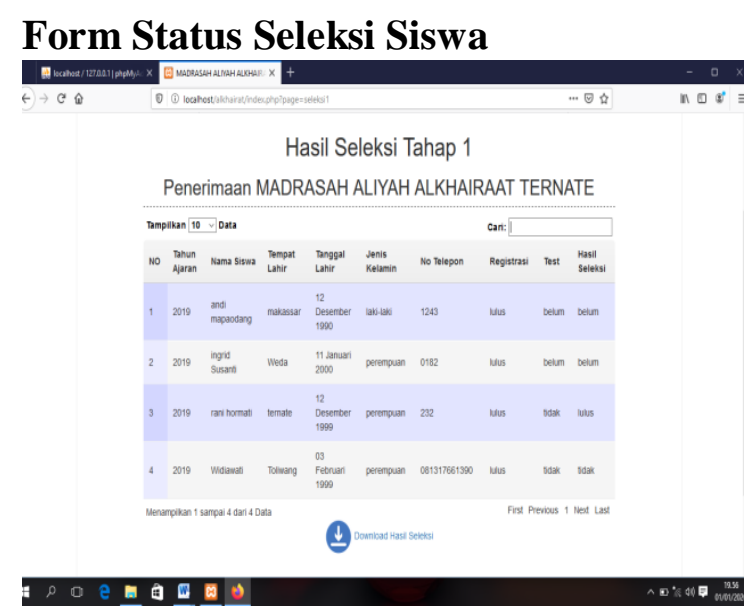

Gambar 14. Form status seleksi siswa

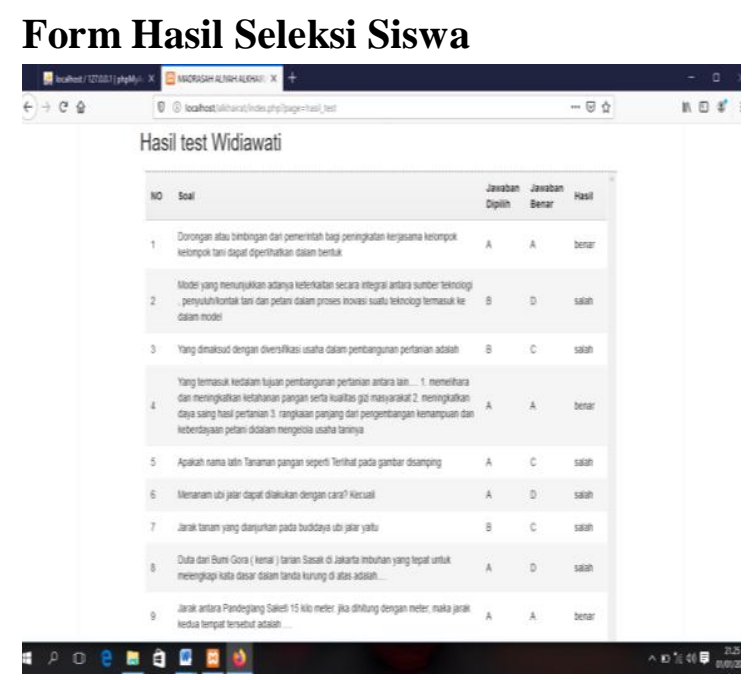

Gambar 15. Form hasil seleksi siswa

\section{Form Cetak Hasil Seleksi Siswa}

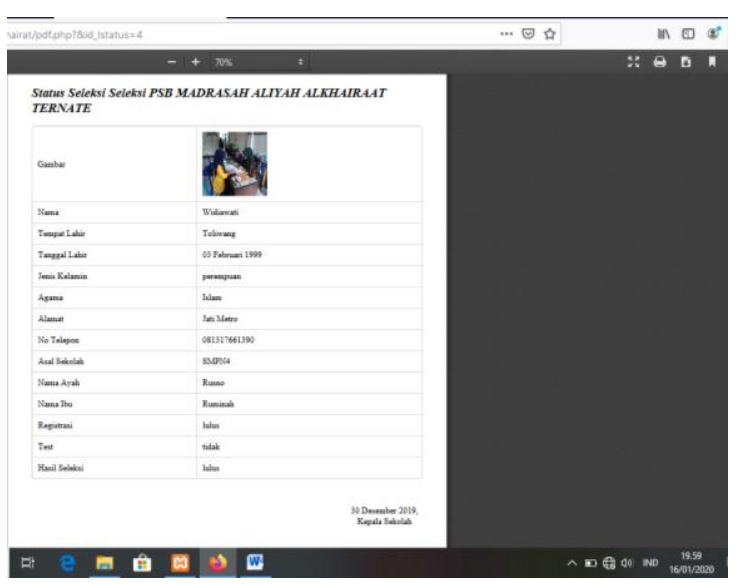

Gambar 16. Form cetak hasil seleksi siswa

\section{Form Grafik Pendaftaran}

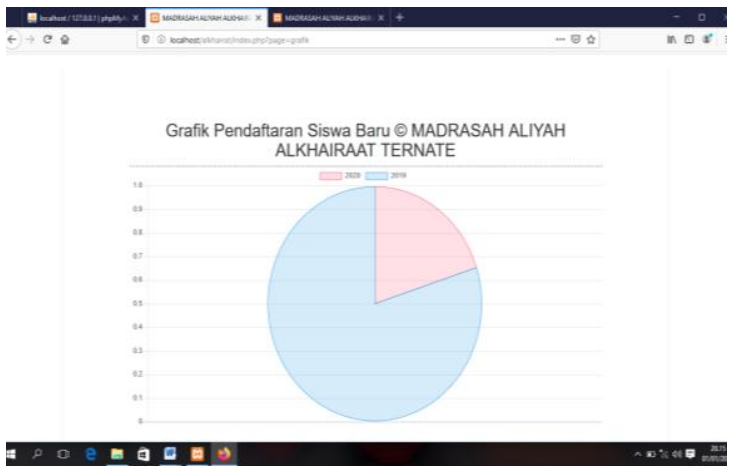

Gambar 17. Form grafik pendaftaran

\section{Pengujian Sistem}

Pengujian sistem sangatlah penting dalam pembangunan sebuah perangkat lunak, karena dengan melakukan pengujian sistem tentu dapat menemukan kesalahan-kesalahan pada sistem dan memastikan sistem yang dibangun telah sesuai dengan apa yang direncanakan sebelumnya. Adapun metode yang digunakan dalam pengujian sistem ini adalah black box, Pengujian black box berfokus pada persyaratan fungsionalitas perangkat lunak. Berikut merupakan tabel pengujian sistem:

\section{KESIMPULAN}

Berdasarkan perancangan dan implementasi perangkat lunak maka dapat disimpulkan sebagai berikut: 
1. Sistem Seleksi siswa baru ini diakses secara online, siswa baru melakukan pendaftaran, melakukan tes, dan melihat informasi kelulusan, kemudian admin akan mengkonfirmasi hasil dari pendaftaran dan kelulusan seleksi siswa baru.

2. Sistem ini dibuat untuk mempermudah pihak sekolah dalam hal mengelola, data pendaftaran, seleksi dan menginformasikan kelulusan siswa baru, sedangkan untuk siswa baru sistem ini dapat mempermudah pada proses pendaftaran, seleksi, serta kelulusan siswa.

3. Sistem ini dapat diakses secara luas oleh masyarakat, diharapkan bisa memberikan informasi yang jelas, logis dan akurat.

\section{Saran}

Pembuatan perancangan website sistem seleksi siswa baru yang dibangun masih jauh dari kata sempurna, untuk itu aplikasi ini diharapkan dapat menjadi salah satu bahan atau referensi bagi pembaca dan pengembang lainnya agar lebih baik lagi untuk meningkatkan Perancangan Website Sistem Seleksi Siswa Baru menggunakan Framework CodeIgniter pada Madrasah Aliyah Alkhairaat Kota Ternate, yaitu sebagai berikut:

1. Sistem ini belum menyediakan layanan pemisah data antara data siswa lulus dan siswa tidak lulus, semuanya terangkum menjadi satu, pada saat pencetakan data seleksi siswa.

2. Sistem ini akan lebih baik jika ditambahkan layanan pembayaran pendaftaran dan administrasi secara online, untuk memudahkan siswa pada proses pembayaran. bagi pihak sekolah semoga sistem ini dapat digunakan sebagaimana mestinya serta dapat didaftarkan hosting untuk menjalankan website ini sehingga dapat diakses oleh siswa maupun admin.

\section{DAFTAR PUSTAKA}

A. S., Rosa dan Shalahuddin, M. (2014). Rekayasa Perangkat Lunak Terstruktur Dan Berorientasi Objek. Informatika, Bandung.

Abdullah, Rohi. (2015). Web Programming is Easy. Elex Media Komputindo, Jakarta.

Azhar Susanto, (2013). Sistem Informasi Akuntansi Edisi Sembilan. Andi, Yogyakarta.

Bangun, Wilson. (2012). Manajemen Sumber Daya Manusia. Erlangga, Jakarta.

Djahir dan Pratita. (2015). Sistem Informasi Manajemen, CV. Budi Utama, Yogyakarta.

Donni Joni Priansa, (2016). Perencanaan dan Pengembangan Sumber Daya Manusia. Alfabeta, Bandung.

Hutahaean, J. (2015). Konsep Sistem Informasi, Deepublish, Yogyakarta.

Jauhari Khairul Kawistara, Priyanto Hidayatullah. (2015). Pemrograman $W e b$. Penerbit Informatika, Bandung.

Kasmir, (2016). Manajemen Sumber Daya Manusia. Rajawali Pers, Jakarta.

Kartini, Dwi. (2013). Corporate social responsibility transformasi konsep sustainability management dan implementasi di indonesia. PT Refika Aditama, Bandung.

Purbadian, Yenda. (2016). Trik Cepat Membangun Aplikasi Berbasis Web dengan Framework CodeIgniter, Deepublish (Grup Penerbitan CV Budi Utama), Yogyakarta.

Priyanto, S (2018). Sistem Informasi Pendaftaran Mahasiswa Baru Berbasis Web pada Poltek Wiratama Maluku Utara. Indonesia Journal of Information System (IJIS). Vol.3 No. 1 April 2018, ISSN: 2548-6438.

Supono, dan Virdiandry Putratama. (2016). Pemrograman Web dengan Menggunakan PHP dan Framework 
CodeIgniter. Deepublish (Grup

Penerbitan CV Budi Utama),

Yogyakarta.

Sutarman, (2012). Buku Pengantar Teknologi Informasi, Bumi Aksara, Jakarta

Yani, H.M, Sinambela (2012). Manajemen Sumber Daya Manusia. Mitra Wacana Media, Jakarta.

Yuniva, I (2018). Pendekatan Model Waterfall Dalam Perancangan Web Sistem Informasi Penerimaan Siswa Baru Menggunakan Framework Bootstrap. Paradigma. Vol. XX, No. 1, Maret 2018, p-ISSN 1410-5063, eISSN: 2579-3500. 